\title{
Anchor Establishment Factors: Phenomenological Study of the Rejection Towards Banking Payroll
}

\author{
Aad Satria Permadi \\ Universitas Muhammadiyah Surakarta
}

\author{
Faturochman \\ Universitas Gadjah Mada
}

\begin{abstract}
Muhammadiyah owns 16,346 kindergartens across Indonesia. In Yogyakarta, out of 212 kindergartens listed in the government, 70 belong to Muhammadiyah (30\%). Cumulatively, distribution of money in Yogyakarta's Muhammadiyah kindergarten is significant; however none of the kindergartens use the banking payroll system, making it vulnerable to financial exploitation and corruption. There is a rejection towards this banking payroll system. The current study aims to understand the factors influencing such rejection. Qualitative approach used in the study was phenomenology. Results from in-depth interviews and focus group discussions (FGD) on five teachers showed that anchors were established through the dynamics of two factors: leadership experience and belongingness. Variations between the factors create a new layer of anchor. More participants are needed to better understand the forming of anchors, as well as statistical analysis to validate the new anchor.
\end{abstract}

Keywords: anchor, virtue, material, resistance to change, voice

Muhammadiyah memiliki taman kanak-kanak (TK) sebanyak 16,346 se-Indonesia. Di kota Yogyakarta, dari 212 TK yang terdaftar di pemerintahan, 70 di antaranya adalah TK milik Muhammadiyah (33\%). Secara kumulatif, perputaran uang di TK Muhammadiyah Yogyakarta sangat besar, namun seluruh TK Muhammadiyah ini belum menggunakan sistem penggajian via bank, sehingga rentan terhadap kebocoran keuangan dan tindak korupsi. Ada penolakan terhadap penggajian via bank di TK Muhammadiyah. Penelitian ini hendak memahami faktor apa sajakah yang memengaruhi penolakan tersebut. Pendekatan kualitatif yang digunakan dalam penelitian ini adalah fenomenologis. Hasil wawancara mendalam dan diskusi kelompok terfokus terhadap lima orang guru mengungkapkan bahwa jangkar (anchor) terbentuk dari dinamika dua faktor: pengalaman kepemimpinan dan rasa kebersamaan. Variasi antar-kedua faktor tersebut memunculkan sebuah kemungkinan, adanya struktur lapisan jangkar (layer of anchor) baru. Perluasan variasi partisipan penelitian diperlukan untuk melengkapi sudut pandang dan rasionalisasi penelitian terkait faktor pembentuk jangkar. Uji korelasi statistik juga diperlukan untuk menjawab apakah lapisan jangkar baru ini benar atau tidak.

Kata kunci: jangkar, kebajikan, materi, menolak perubahan, bersuara

In 2006, the Muhammadiyah published an anticorruption fiqih (study of laws pertaining to ritual obligations) (Anwar et al., 2006) and has relentlessly tried to minimize potential corruption in its circle of charity efforts (AUM). This was intensified when the government established BKN head rule number 7 year 2008, requiring civil servants to use banking payroll system (Badan Kepegawaian Negara, 2008).

We would like to thank Dr. Bagus Riyono for the discussion and insight through the theory "In Search of Anchors ".

Correspondence concerning this article should be addressed to Aad Satria Permadi, Faculty of Psychology, University of Muhammadiyah Surakarta, Jalan Jend. A Yani, Solo 50174. E-mail: Aad.Satria@ ums.ac.id
AUM managers took this as an inspiration to move forward with their anti-corruption efforts, leading them to apply the banking payroll system to the payment system of their members. This was considered as an effective way to prevent corruption, due to its transparency and accountability.

Some AUM such as Muhammadiyah-owned high school and universities have applied the banking payroll system. However, not all AUMs have done so. One such AUM that has yet to apply the system is TK Aisyiyah Bustanul Athfal (TK ABA), belonging to an autonomous Muhammadiyah organization (ORTOM) called Aisyiyah. Distribution of 
money in TK ABA is significantly smaller compared to that of a Muhammadiyah university. However, the distribution is actually quite significant cumulatively speaking due to the sheer number of TK ABAs, totalling 16.346 kindergartens across Indonesia ("Laporan Pertanggung Jawaban," 2015).

TK is the biggest AUM owned by the Muhammadiyah compared to other AUMS; university (192), schools (5105) and hospitals (557). In Yogyakarta, 70 out of 212 kindergartens are TK ABA (DIKPORA, 2015), and none of them have applied the banking payroll system at least according to the headmaster of this kindergarten who is also an Aisyiyah staff in Yogyakarta. Such significant number of kindergarten, combined with a conventional payroll system, makes it easier to engage in financial exploitations or corruptions.

One major cause of this lack of application is the rejection of the banking system by the teachers. This occurred in a TK ABA in southern Yogyakarta. The rejection occurred in the 2010 teaching period. Teachers also boycotted the headmaster who initiated the banking payroll policy. There are two main reasons: first, teachers do not want their pay to be cut by administrative fees. Two, the teachers fear that upon finding out the amount of their pay, people may look down on them due to the minimal wage received in one of the best kindergartens in Yogyakarta. Sixteen out of 18 teachers in the kindergarten rejected the banking payroll system.

Only two teachers supported the banking payroll system. They considered the system as a way to increase their work efficiency and competence. Interestingly, these two supporters also recognize the same risks of applying the system similar to those who reject it.

The phenomenon of changing payroll system, from conventional payment to banking payroll, is a consequence of persistent changes in the environment (Randolph \& Dess, 1984). In responding to the change, some organizations are capable of adapting, while others are not. Inability to adapt is regarded as a sign of organizational decline (Ancok, 2005).

Theoretically, rejection to change can be classified into two: resistance to change and voice (Holtzman, 1993). Voice is a form of rejection through dialogue and discussion (Zhou \& George, 2001). Protesters meet policy makers and discuss the flaws of the new policy, and provide alternative solutions to the problem (Pardo del val \& Fuentes, 2003).

On the other hand, resistance to change aims to protect the status quo (Burton, Lauridsen, \& Obel,
1999), by frequently becoming trouble makers (Dent \& Goldberg, 1999), focusing on flaws and ignoring beneficial achievements of the new policy (Krantz, 1999; Piderit, 2000).

From a motivational point of view, rejection to change reflects an individual's inability to find meaning in the change. Frankl (1992) stated that the source of motivation is "the will to meaning," the human ability to understand complex situations in different ways. Meaning according to Frankl is very unique, to a point where Boeree (1988) stated that meaning is not a social value; it is a spiritual value residing outside of the physical and psychological realm enabling to help people function autonomously, not just merely responding to environmental stressors.

Somani (Devoe, 2012) stated that the act of finding meaning has nothing to do with spirituality and religion, but it has a direct connection with an individual's life goals. An individual's life goal is very subjective, and thus each individual need to find the meaning themselves and be accountable to it (Frankl, 1992).

Some theories can explain the phenomenon of rejection to change. One theory is the theory 'in search of anchor' (Riyono, 2012; Riyono, Himam, \& Subandi, 2012). Anchors are values held by individuals when facing psychological in-equilibrium due to a stressor.

There are various forms of anchors, categorized into five layers: (1) God, as the ultimate abstract anchor. An example of this is the value of honesty; (2) Virtues, are long lasting life principles that

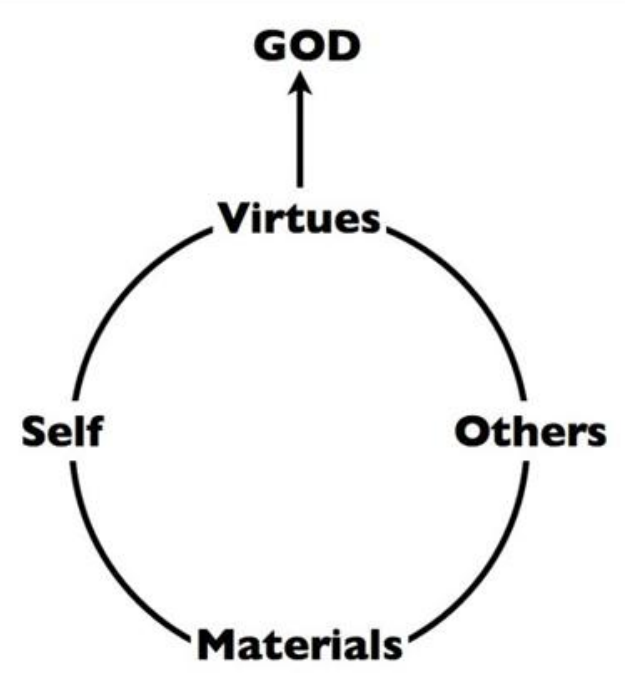

Figure 1. The structure of anchor. (Riyono, 2012, p. 198) 
Table 1

Categorization of Participants Based on Their

Response on Banking Payroll

\begin{tabular}{cc}
\hline Behavior & Number of Participants \\
\hline Resistance to Change & 2 (ALF \& FTR) \\
Voice & 1 (ZRH) \\
Support & 2 (JND \& JML) \\
\hline
\end{tabular}

Table 2

Categorization of Participants Based on

Anchor and Origin Factors

\begin{tabular}{cccc}
\hline Participant & $\begin{array}{c}\text { Leadership } \\
\text { Experience }\end{array}$ & Belongingness & Anchor \\
\hline FTR & No (L.5) & No & Self \\
ALF & No (L.2) & No & Material \\
JML & Yes (L.11) & Yes & Virtues \\
JND & Yes (L.11) & Yes & Virtues \\
ZRH & No (L.7) & Yes & Others \\
\hline
\end{tabular}

cannot be denied in social or natural life. An example is the principle of honesty; (3) Self, which is every form of the individual related to selfconcept; (4) Others, which include other people and groups where the individual belongs to; and (5) Materials, which are valuable physical possessions such as money and jewelry.

The structure of anchor is hierarchical. The bottom-most anchor (materials) is the lowest anchor, while virtues are the highest. Individuals will have the worst motivation when depending on the materials anchor, while those who focus on virtues anchor will find meaning and increased motivations. Those with self and other anchors should have the same level of motivation as seen in the diagram.

Riyono (2012) stated that individuals will find meaning from the stressors faced if he/she focuses on the anchor of virtues, which are manifestations of the values of God. Anchor of virtues create meaning for the individual. This protects his/her psychological being because the stressor is assigned a positive meaning. For example, individuals can experience frustration when assigned to another position if he views the change as punishment or inability to work (self-focused anchor). However, changes in position will be a positive challenge if he views it as a way to develop his other potentials (virtue-focused anchor).

The difference between Riyono and Frankl's anchor is the ultimate anchor. Frankl considered anchor of virtues as something achieved by the individual through his own subjective search, while
Riyono stated that virtues are achieved from outside the individual, which are vales of God. This has an impact on the psychological effect of anchors. Frankl focused the search of meaning on the self, and does so very conditionally. This means that anchor of virtues according to Frankl can change because an individual is only accountable for himself. Subjective search for meaning may thus bring psychological inequilibrium because it requires specific skills. The concept provided by Riyono explained anchor of virtues as something more stable, as individuals are no longer accountable to fellow human beings, but to God. In that position, an individual's psychological state will be more stable due to his/her focus on God.

The main method used by Riyono (2012) in creating his theory is a quantitative-experimental method in the context of education (university students' motivation), with in-depth interviews of seven participants. All participants studied in Indonesia, with two originally coming from Germany, male and female. Riyono's study has yet to explain how anchors form in individuals. The current study aims to complement Riyono's (2012) study in terms of the process of establishing anchors in the context of organizational behavior, with homogenous participants (women).

\section{Method}

The current study uses a qualitative method with phenomenological approach. Participants were five kindergarten teachers (JND, ZRH, JML, ALF, and FTR) who teach in a kindergarten in south Yogyakarta. Participants were recruited through purposive sampling, taking representatives of those who are for and against the banking payroll program. Three out of five respondents are against the idea (ZRH, ALF, FTR) while two (JND and JML) support the program (see Table 1).

Data were collected using in-depth interviews and focus group discussions (FGD). The interview used a semi-structured guide, where main questions were asked, and participants' answers become ideas to develop further questions. Participants were found through a snowball method. The first participant found supported the banking payroll program, and this participant recommended others who support and resist the program.

FGD was only done on those who reject the program because those who support it felt unnecessary to undergo FGD. JND said that they 
(JND and JML) are in complete agreement. Collected data were analyzed in stages. The first stage is coding. All data were coded as themes (open coding). Similar themes are then grouped and narrated into a storyline. The next stage is grouping different themes into new meaning (axial coding) in the form of individual dynamic phenomena (IDP). The last stage is to establish the core phenomenon.

The first data presented was the participants' anchor. Participants were categorized into different anchors according to Riyono (2012) based on keywords and answers. The next step was to reveal the factors creating the participants' anchor. Analysis was done with an expert and peers in a peer group discussion.

\section{Results}

From the collected data, the five participants were grouped as follows (see Table 2).

Leadership experience refers to the participants' experience of managing the head of an organization in a full period (five years). With a minimum of one period in leading, it was assumed that individuals have a relatively firm experience in leadership, at least in the level of her responsibility. Hypothetically, an individual's organizational experience is related to leadership, as depicted in Figure 2.

Participants were considered to have leadership experience when they were located at level 9 (L. 9) or level 11 (L. 11). From Table 2, it can be seen that ALF, FTR, and ZRH have no leadership experience. Only FTR and ZRH have had organizational experience, but not as a leader.

"I have joined the branch [PC NA Umbulharjo] once, for one period. I was not very active. Even if I was invited I sometimes didn't go. It was a very tough period, so if there was a meeting there were only probably five people at the time".

(IDP FTR, episode 13).

"I was there until I became a subsidiary. Member of PCNA, also a branch [member]"

(IDP ZRH, episode 6).

"So if I'm confused I end up not joining an organization." (IDP ALF, episode 10).

"Pernah ikut cabang [PC NA Umbulharjo] itu saya mas sekali, satu periode. saya itu gak aktif banget. wong ono undangan yo kadang yo rak mangkat seperti itu saya itu. wong itu pas periode saya itu memang sangatlah terpuruk nganu mas. Dadi nek pertemuan itu, nek ada pertemuan cabang yang berangkat lima seperti itu lho mas pada saat itu”. (IDP FTR, episode 13).

"Saya di nganu [NA] pernah sampai cabang. Anggota PCNA, ranting juga [anggota]”, katanya (IDP ZRH, episode 6).

"Dadi nek malah bingung saya dadi malah gak ikut organisasi. (IDP ALF, episode 10).

Participants JML and JND have leadership experience. JML is one of the leaders of Pimpinan Pusat Nasyi'atul Aisyiyah (NA) and JND is a headmaster for three consecutive periods. JND have also received an award for being the model headmaster on a national level.

"Started joining nasi'ah (NA) at a branch in eighty eight (1988). Insyaallah never stopped [being a part of an organization from 1988 until now]. Now in central [NA command]. [Holds a position as leader in field three [at NA Central Command]". (IDP JML, episode 17).

"Mulai gabung di nasi'ah (NA) di ranting tahun lapan lapan [1988]. Insyaallah nggak putus [berorganisasi sejak tahun 1988 sampai sekarang]. Sekarang di [pimpinan] pusat [NA]. [menjabat sebagai] Ketua bidang tiga [di Pimpinan Pusat NA]."

(IDP JML, episode 17).

Belongingness is operationalized with OCB. This is in line with the view expressed by Den Hartog et al. (2007). ALF and FTR did not exhibit OCB behavior, which is confirmed by their colleague, $\mathrm{ZRH}$.

"Sometimes here [teachers at TK Mawar, including those who reject the banking payroll], everything is measured with money, I am very tired. For example regarding accreditation, the last time we had accreditation, when everyone was busy dealing with accreditation, the compensation we received were different [compared to one teacher with another]. That became a problem, some [teachers] did not accept it [the different amount of money they got]. That made it insincere."

(IDP ZRH, episode 3). 
"Kadang-kadang disini [guru-guru TK Mawar, termasuk penolak banking payroll] opo opo dinilai dengan uang, wah aku wis rekoso lho, wingi anu, misalnya mau akreditasi. kemarin akreditasi itu saja yang waktu itu bener-bener ubrek ne' nggo' akreditasi dengan orang yang uang lelahnya kan tu bedo. itu pun jadi tanda kutip [jadi] masalah, ono sing ora trimo nek awake dewe disini tu tidak ikhlas po. ra trimo terus". (IDP ZRH, episode 3).

According to the data, $\mathrm{ZRH}$ is a participant recognized by her colleagues as an individual with OCB. This is why ZRH explained what teachers should do when the school needed help, just like what she has been doing.

"When the school has problems, we should at least try and lend our aid in terms of mind, effort, and time". (IDP ZRH, episode 12).

"Nek ada kerepotan apa di sekolah itu yo awake dewe lah setidaknya mencurahkan nek iso pikiran, ne iso tenaga, nek iso waktu opo".

(IDP ZRH, episode 12).

Similar to ZRH, JML and JND also display OCB behavior. JND is the headmaster of the kindergarten, who often comes even during school holidays to finish outstanding work. This includes the school's cleanliness as well as administration, even doing tasks that may not be her responsibility.

"Because I live nearby, in the same area, and if there's a competition or a guest I don't think twice, I mean I think about it, it's not very good there, at most I go there in the evening or at night, and when I was young and unmarried, when the class were only two built with plywood and net I bring my sibling with me. After my shubuh prayer, the musholla here also has congregation members even it's relatively small. I wait until they go home, and then I come with my little brother to help clean up and put it in order".

(IDP JND, episode 5).

"Karena rumah saya dekat, mungkin hanya di kampung situ, dan istilahnya kalo mungkin mau lomba, mau ada tamu itu saya nggak pikir pikir, maksudnya itu kepikiran, di sana itu kurang wangun, semaksimalnya itu saya maksudnya sore datang ke sini lagi, malem ke sini lagi, bahkan dulu kalo saya masih muda itu tidak punya pak bon, kelasnya dua kelas yang tadi dari triplek dan jaring - jaring itu saya ngajak adik saya, ee habis shalat subuh di masjid sana, sini mushola juga ada yang jama'ah, tapi relatif sedikit. Saya nunggu kira - kira yang jama'ah sudah pulang, saya datang dengan adik saya, adik saya lakilaki tak jak untuk bersihkan nanti setelah saya toto saya rapikan”. (IDP JND, episode 5).

One reason why JML supports banking payroll is her belongingness to the organization

"Who else will put their trust in there if not us [people/family of Muhammadiyah]. Because Muhammadiyah is family". (IDP JML, episode 4).

"Siapa lagi yang mau menaruh kepercayaan di situ kalo bukan sesama [warga/keluarga Muhammadiyah]. Karena yo di Muhammadiyah itu kan keluarga". (IDP JML, episode 4).

ALF rejects banking payroll because it is financially detrimental. ALF does not want her already miniscule pay to be cut by administrative banking fees. FTR also rejects the program but for different reasons. FTR is embarrassed to receive a pay through the bank because of how little she gets paid. FTR predicts that her small wage will be a topic of discussion for bank staff members and may spread to other people in the community.

"Usually we leave the rest [administrative fee]. So for example if we get paid one million, then we [should] receive one million. There [at the bank] will be cuts, and we don't like that because it reduces our pay". (IDP ALF, episode 2).

"How does it feel, we feel embarrassed from the... nominal value". (IDP FTR, episode 2)

"Biasanya kan kita meninggalkan sisanya [biaya administratif]. Jadi, kita misalnya gajinya satu juta, ya kita [harusnya] nerimanya satu juta. Kalo di sana [bank] nanti ada potongannya itu, nha itu yang nggak kami suka, karena berkurang itu"

(IDP ALF, episode 2).

"Rasanya kan gimana ya, wong kita, kita tu malunya dari segi e... nominalnya"

(IDP FTR, episode 2) 
ZRH rejects banking payroll for a different reason. She considered the program as a potential threat to the harmony between teachers, and will negatively affect work motivation.

"I just want all of us to get along and move on, when someone gets troubled by a minor problem about wage, it can make others less willing to work". (IDP ZRH, episode 8).

"Saya kan pinginnya e kabeh kan rukun sesuatu yang yang opo yo wes berjalan lah. mau awake dewe hanya karena persoalan kecil tentang penggajian gitu aja, terus mara'ke ora semangat untuk bekerja". (IDP ZRH, episode 8).

JML and JND supports banking payroll for strategic reasons. JML stated that banking payroll will increase TK Mawar's organizational competence, while JND said that it will increase organizational efficiency.

"I like it [the program banking payroll] because, we haven't had it yet, from a kindergarten at least it will be a positive point for education, daring to try something different, that's the first."

(IDP JML, episode 1).

"Because through BMT, our staff doesn't have to take the money, it's already there. That's very convenient for me." (IDP JND, episode 1).

Saya sukaknya [pada program banking payroll] gini, namanya belum pernah, dari TK ya seperti itu, paling enggak nilai tambah untuk pendidikan berani mencoba sesuatu yang mungkin beda dengan yang lain, itu yang pertama." (IDP JML, episode 1).
"Karena kalo lewat BMT kayanya lebih ini, uang juga karyawan kami nggak usah ngambil, dah langsung di situ. Kan penak banget gitu lho, bagi saya itu” (IDP JND, episode 1).

\section{Discussion}

Participant's anchor is seen from the reason they support or reject banking payroll. Material-focused reasoning is seen as anchor of materials. Reasons related to social harmony are seen as anchor of others. Other reasons related to factors that improve the organizations are seen as anchor of values (JML and JND).

From the data collected, leadership experience is a deciding factor for the creation of anchor of virtues. Participants who support the banking payroll all had leadership experience that enabled them to understand the strategic benefit of the program to the organization.

Belongingness places an individual on anchor of material. In this scenario, individuals improve their anchor on anchor of others and anchor of virtues. Those who lack belongingness were motivated by anchor of materials, while those who have it avoided anchor of materials. Participants who have belongingness but lacks leadership experience such as ZRH did not attain anchor of virtues, because banking payroll is a strategic program that can only be understood by others who have leadership experience such as JML and JND.

JML and JND have significant leadership experience as top leaders in an organization. JML has been involved in an organization for 18 years, and she is currently one of the leaders at Pimpinan Pusat (PP) Nasyi' atul 'Aisyiah, while JND has been holding a position as a headmaster for 15 years (three periods).

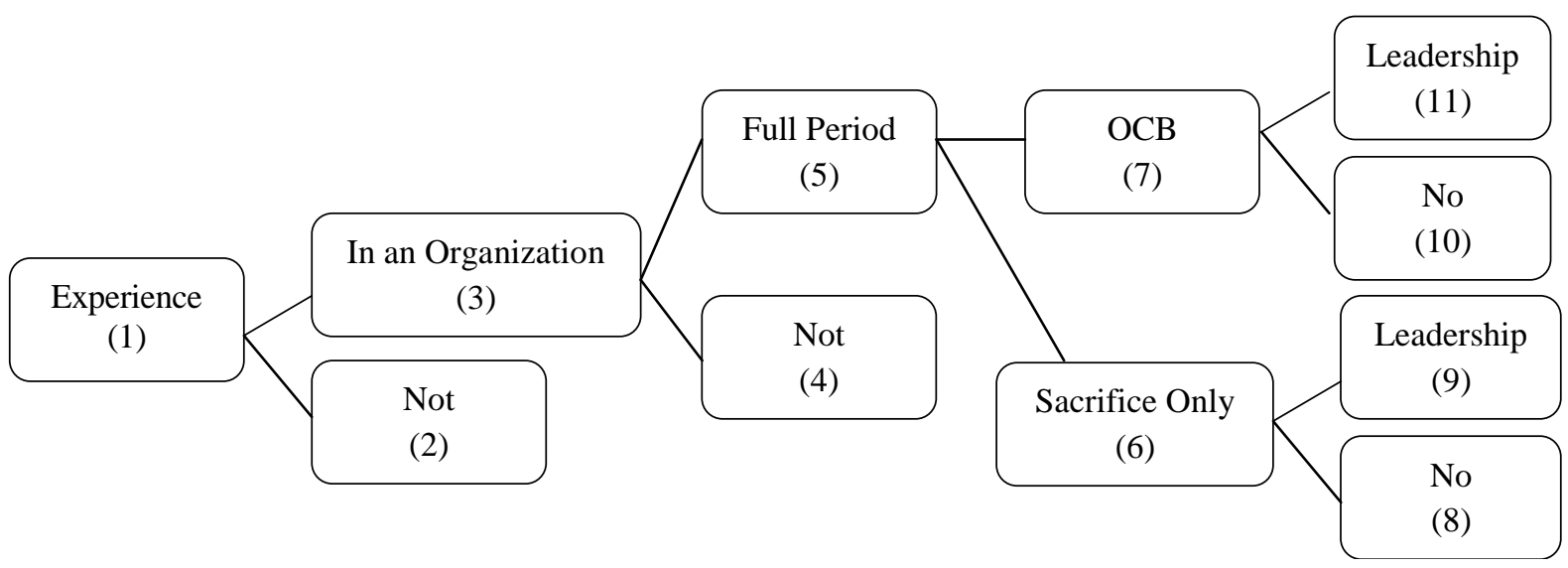

Figure 2. Level of organizational experience. 
Such organizational experience enabled them to understand the strategic organizational benefit of the banking payroll.

TK Mawar and NA are organizations that are directly affiliated with Muhammadiyah, and as such the significant organizational experience from JML and JND created a sense of belongingness not just in TK Mawar but also on Muhammadiyah. Improvements in TK Mawar are also an improvement for Muhammadiyah. This is what JML feels. She feels that banking payroll will improve TK Mawar, and it is the responsibility of each member of the Muhammadiyah. As a headmaster with the longest serving period, JND also feels a sense of belongingness. This is shown by her routine activity doing outstanding tasks that her employee has yet to finish, even during school holidays.

The length of time spent understanding an organization is a factor that creates belongingness
(Hoogervorst, N., Cremer, D.D., Dijke, M.V., \& Mayer, D.M. (2012).). In Indonesian society, especially Java, the theory by Hoogervorst is already well known because Javanese people have under-stood the expression "tresno jalaran soko kulino" (love due to being accustomed). Participants JND, JML, and ZRH have spent a considerable amount of time understanding the Muhammadiyah, and as such their ego is attached to the organization, or in group psychology terms, they felt that they belonged to the group (Hartog, Hoogh, \& Keegan, 2007). For them, organizational decline creates psychological discomfort, whereas organizational improvement creates personal psychological com-fort. This is why they always try to improve the organization in many different ways.

Banking payroll is a program that can improve the organization when considered from the perspective of participants who have leadership expe-
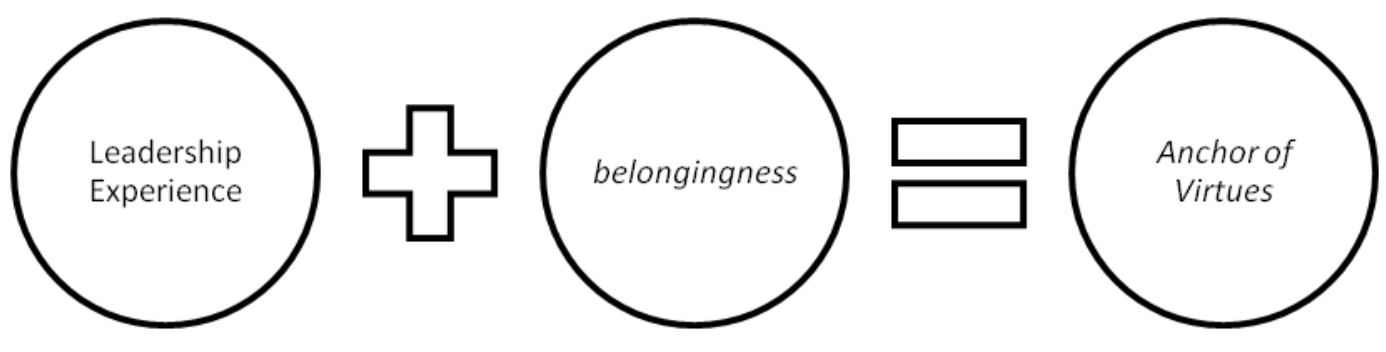

Figure 3. Factors forming anchor of virtues.
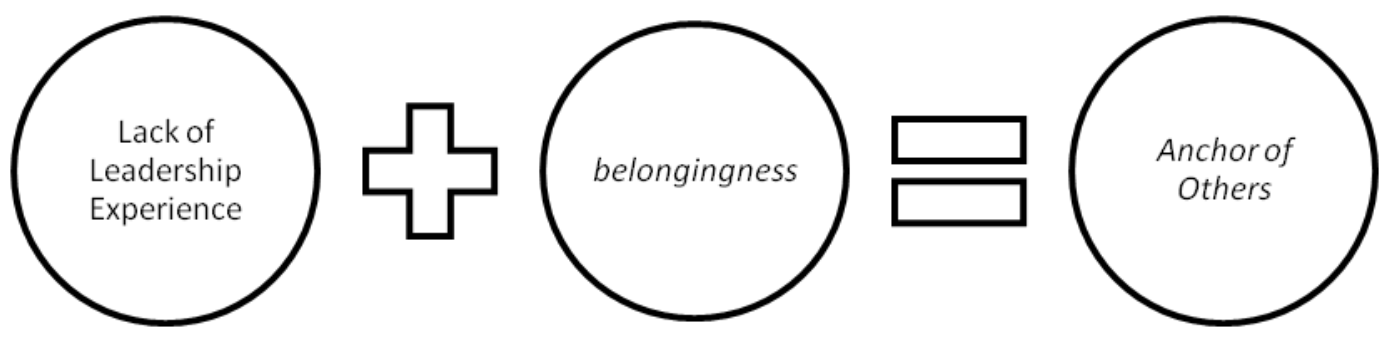

Figure 4. Factors forming anchor of others.
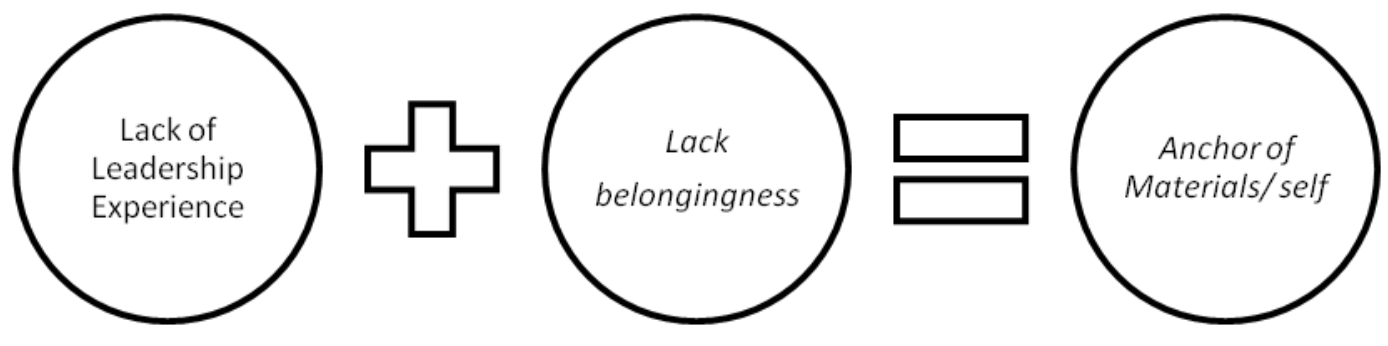

Figure 5. Factors forming anchor of materials/self. 
rience. The benefits include increasing performance efficiency and adding value to the kindergarten for being the only kindergarten that is financially trustworthy due to its usage of the banking payroll, enabling the kindergarten to survive amidst the increasing competition with other kindergarten in Yogyakarta city. Such understanding then interacts with belongingness that always works for the improvement of the organization. The interaction of principle organizational strategies and belongingness leads to the support of banking payroll. Such support occurs because participants have found meaning in the banking payroll, called anchor of virtues (see Figure 3).

Anchor of others (see Figure 4), such as the one in $\mathrm{ZRH}$, was formed from the interaction of lack of leadership experience and belongingness. ZRH does not understand the strategic implications of banking payroll, but her belongingness lifted her anchor from materials to other oriented. The tendency on anchor of others was mainly due to the prolonged experience of being in the lower structure in an organization, where actions have direct influences on the stakeholders. In her lack of understanding about the strategic benefits of banking payroll, $\mathrm{ZRH}$ is more influenced by her sense of belongingness, where the most important thing is that each decision should not disturb the stability of organizational performance. ZRH feels uncomfortable towards the conflict between those who support and those who are against the banking payroll in TK Mawar because she considered the conflict as a threat to organizational stability.

Thus, ZRH rejects banking payroll through voice. $\mathrm{ZRH}$ rejects the program because she considers it as a cause of conflict. She chose to voice her rejection because she does not wish to create new conflict, and she believes that supporters of the banking payroll can be persuaded to engage in a discussion through voice. This is a different method compared to FTR and ALF who chose resistance to change. FTR and ALF have joined with other teachers to engage in a boycott towards the banking payroll. They do not care about organizational stability, as seen by their way of resisting change. This is primarily because FTR and ALF did not have a sense of belongingness towards TK Mawar.

Participants with anchor of materials or anchor of self, rejects banking payroll because they see it as being detrimental to themselves. This can occur because participants lack leadership experience, making them unable to understand the strategic organizational benefits of banking payroll. Participants become aware of the material excuses due to their lack of belongingness to TK Mawar, making them aware only for themselves and the negative impacts of the banking payroll, which are financial losses and embarrassment.

From Figure 5, it can be seen that individuals who do not have leadership experience or belongingness display a different anchor. Participant FTR has anchor of self, while ALF has anchor of materials. Theoretically, they should have the same anchor, or their anchors should be on the same level. Data showed that ALF and PTR have different tendencies in responding to banking payroll, and this makes it difficult to conclude whether they have the same anchor. It is possible that anchor of materials and anchor of self are actually on the same level. If so, a new depiction of the layers of anchors would be as follows.

The anchor structure depicted in Figure 6 can be read the same way as the layer of anchor structure according to Riyono (2012). Individuals will have low motivation when located on anchor of self and anchor of materials, and these two anchors are equal. These two anchors have equal effects because ultimately people who are on this level care only for themselves. This is seen from the data that showed how even though participants may reject the banking payroll due to their low wage (mate-

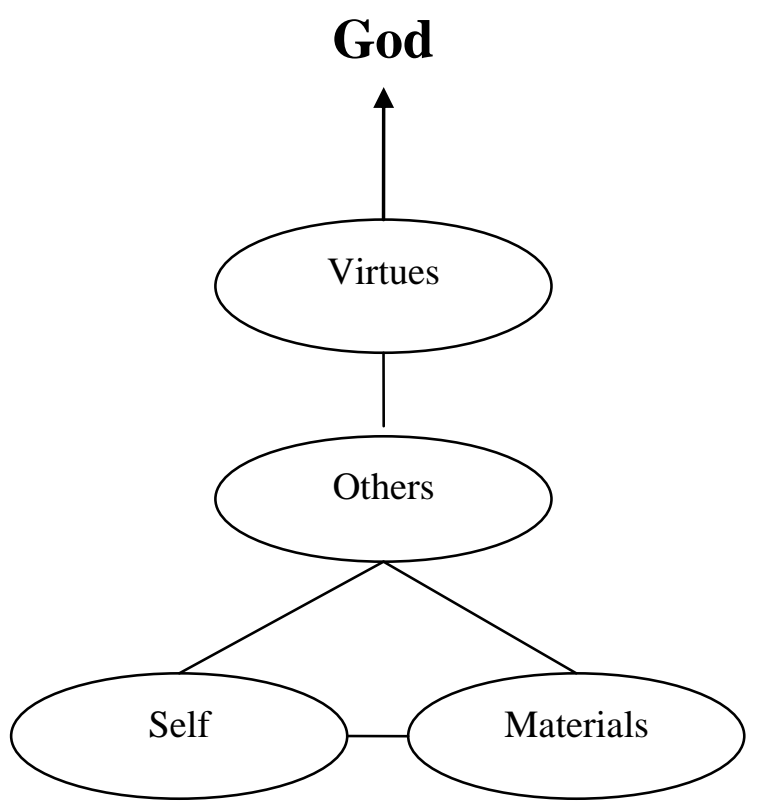

Figure 6. New structure of layer of anchors. (A hypothesis) 
rials), this is also closely related with their embarrassment towards their pay should it become known to the public eye. This means that materials motive (pay) is very closely related to embarrassment motive (shame). This idea is further validated in the focus group discussion, where participants stated that if they receive a larger amount of pay, they would not mind the banking payroll system.

Findings from the current research cannot be generalized to every context because the focus was on the dynamics of organizational change related to finances, and the psychological dynamics of women. Therefore, the findings should be complemented with other research contexts, for example organizational change context that are not related to finances, but to leadership, or is more related to the function and role of an individual in an organization. Individual dynamics can also be varied by including more variations in gender, age, and culture.

\section{Limitation and future studies}

The most obvious limitation of this study is that it discussed more dominantly the intrapersonal dynamics, namely the motivation, which later-on being correlated to the actual behavior (rejecting or accepting banking payroll). There is not yet a discussion concerning the interpersonal processes in the rejecting phenomena towards this banking payroll, though to shape into an actual behavior, intrapersonal should interact with the social (interpersonal) world. Studies revealing inter-personal processes should be conducted to explain how the motivational rejection towards banking payroll transforms into resistance to change or voice.

\section{Conclusion and suggestion}

Forming factors of anchor found in the context of rejection towards banking payroll are leadership experience and belongingness. Individuals who support change from conventional payroll to banking payroll are those who have leadership experience and belongingness to the organization. Those who reject the new program lack one or both factors.

Teachers need to be more involved in policymaking processes and other organizational works. This is important to increase strategic-organizational sensitivity as well as belongingness, so that the teachers can become agents for change instead of agents resisting change.

\section{References}

Ancok, D. (2005). Psikologi terapan. Yogyakarta: Darussalam.

Anwar, S., Muhammadiyah, PP, Majelis Tarjih dan Tajdid., Pusat Studi Agama dan Peradaban (PSAP),. Wahid, S.A, Ilyas, H., ... Dahwan (2006). Fikih antikorupsi: Perspektif Ulama Muhammadiyah. Jakarta: PSAP

Boeree. C. G. (1998). Personality theories: Viktor Frankl. Retrieved from http://webspace.ship.edu/ cg-boer/frankl.html.

Burton, R. M., Lauridsen, J., \& Obel, B. (1999). Tension and resistance to change in organizational climate: Managerial implication for a fast paced world. Retrieved from http://www.lok.cbs.dk/images/ publ/Burton $\% 20 \mathrm{og} \% 20$ Obel $\% 20 \mathrm{og} \% 20$ Lauridse n\%20tension\%202000.pdf

Dent, E., \& Goldberg, S. (1999). Challenging resistance to change. Journal of Applied Behavior Science, 35(1), 25-41.

Devoe, D. (2012). Viktor Frankl's logotherapy: The search for purpose and meaning. Retrieved from http://www.studentpulse.com/articles/660/2/vikto r-frankls-logotherapy-the-search-for-purposeand-meaning.

DIKPORA. (2015). Daftar nama dan alamat sekolah. Rettrieved from http://www.pendidikan-diy.go.id /dinas_v4/?view=baca_isi_lengkap\&id_p=8

Frankl, V. E. (1992). Man's search for meaning: An introduction to logotherapy (4th ed.). Boston: Beacon Press Book.

Hartog, D. N., Hoogh, A. H., \& Keegan, A. E. (2007). The interactive effects of belongingness and charisma on helping and compliance. Journal of Applied Psychology, 92(4), 1131-1139.

Holtzman, H. (1993). The path of least resistance leads to growth and profit. Managing Office Technology, 38, 7-10.

Hoogervorst, N., Cremer, D. D., Dijke, M. V., \& Mayer, D. M. (2012). When do leaders sacrifice?: The effects of sense of power and belongingness on leader self-sacrifice. The Leadership Quarterly, 23(5), 883-896.

Krantz, J. (1999). Comment on "challenging resistance to change". Journal of Applied Behavioral Science, 35(1), 42-44.

Laporan pertanggung-jawaban PP Muhammadiyah periode 2010-2015. (2015, August). Presented at the Muhammadiyah advisory meeting (sidang tanwir), held at the University of Muhammadiyah Makasar. 
Pardo del val, M., \& Fuentes, C. (2003). Resistance to change: Literature review of empirical studies. Management Decision, 41(2), 26-32.

Piderit, S. (2000). Rethinking resistance and recognising ambivalence: A multidimensional view of attitude toward an organizational change. Academy of Management Review, 25(4), 783-794.

Randolph, W. A., \& Dess, G. G. (1984). The congruence perspective of organization design: A conceptual model and multivariate research approach. Academy of Management Review, 1, 114-127
Riyono, B. (2012). Motivasi dengan perspektif psikologi Islam. Yogyakarta: Quality Publishing.

Riyono, B., Himam, F., \& Subandi (2012). In search of anchors: The fundamental motivational force in compensating human vulnerability. Gadjah Mada International Journal of Business, 14(3), 229-252.

Zhou, J., \& George, J. (2001). When job dissatisfaction leads to creativity: Encouraging the expression of voice. Academy of Management Journal, 44(4), 692-686. 